\title{
Рад јавних библиотека у Србији у ванредним условима изазваним пандемијом Covid-19
}

\author{
Предраг Јеремић \\ pega.jeremic@gmail.com \\ Драгана Сабовљев \\ dragana.sabovljev@gmail.com \\ Градска народна библиотека „Жарко Зрењанин“, Зрењанин
}

\begin{abstract}
Сажетак
Текст се бави анализом рада јавних библиотека у Србији у условима изазваним пандемијом корона вируса. Заснован је на Упитнику који је послат на адресе библиотекара матичних служби, чланова Секције за Матичне библиотеке Библиотекарског друштва Србије. С обзиром на то да је на њега одговорило мање од половине колега, аутори су своја сазнања допунили подацима из излагања која су чули на Библионету 2021 у Лесковцу, посвећеном овој теми. Изложени су и протумачени одговори испитаника, а пажња је посвећена и активностима јавних библиотека на њиховим званичним вебстранама и на друштвеним мрежама. Резултат овог истраживања је преглед делатности библиотека у условима ванредног стања и непосредне опасности по здравље и животе људи који приказује преусмеравање комуникације са корисницима од традиционалног пружања услуга у просторијама институција на ново, дигитално окружење. Доказано је да су се ове установе веома брзо и успешно прилагодиле новим околностима и да су успеле да анимирају нову корисничку групу представљањем својих фондова, збирки, изложби, манифестација и различитих активности у виртуелном свету.
\end{abstract}

Кључне речи: јавне библиотеке, Република Србија, пандемија Covid-19, веб-странице, друштвене мреже, фондови библиотека, дигиталне технологије, промотивне активности, онлајн услуге

\section{Увод}

Пандемија Covid-19 донела је промене у свим сегментима комуникације међу људима у читавом свету. Пословање свих институција које нису од виталног значаја за живот, као и контакти, пребачени су у виртуелно окружење. Једини начин за очување живота и здравља који се препоручивао и препоручује се у одговорним друштвима јесте рад од куће тамо где је могуће, избегавање непосредних контаката, ношење заштитних маски и дезинфекција и одржавање хигијене радних простора и домаћинстава. Библиотеке, као установе које највећим делом постоје због услуга које пружају корисницима и у служби су заједнице, доживеле су ограничења у својој основној делатности. Са великом сигурношћу се може тврдити да се човечанство у целини није најбоље снашло у новонасталим околностима, а сазнања о вирусу, његовим мутацијама, лечењу, вакцинацији, а са друге стране негирање вируса, одбијање да се поштују прописане мере, антивакцинални покрети, доносе нова правила понашања. И рад библиотека организован је на различите начине, у складу са прописима и упутствима које су издавали надлежни органи у циљу заштите здравља и живота људи, али се умногоме засновао и на појединачним проценама носилаца локалне власти и руководилаца ових установа, што је донело прилично разнолико понашање. 
Задатак овог чланка јесте да представи рад јавних библиотека у Србији у условима изазваним пандемијом Covid-19. Овом приликом наша искуства нису упоређивана са онима из других земаља. За писање текста коришћени су подаци добијени имејл анкетом спроведеном међу члановима Матичне секције Библиотекарског друштва Србије (БДС), као и презентације колега које су излагале на Библионету 2021 у Лесковцу - „Библиотека од куће: изазови и могућности организације библиотечких услуга током пандемије“. С обзиром на то да су појединачни примери добре праксе већ објављивани у периодичним публикацијама, аутори овог рада су покушали да сачине само један приказ деловања јавних библиотека. Такође, у овом контексту су представљени упутства и законска акта која се односе на деловање у ванредним условима, као и садржаји које су библиотеке нудиле својим корисницима путем друштвених мрежа и различитих медија.

\section{Упитник о раду у условима пандемије Covid-19}

Упитник о раду библиотека у време пандемије послат је на 25 адреса чланова Секције за Матичне послове БДС. Разлог за овакав избор испитаника била је чињеница да библиотекари ових служби имају најцеловитији увид у деловање матичне библиотеке. На њега је одговорило 12 библиотекара, што чини мање од половине колега које су прихватиле да учествују у овој анкети. Податак звучи прилично поразно, али требало би имати у виду да су многи већ писали радове или излагали на скуповима на ову тему, па је могуће да нису били вољни да се поново баве њоме. Иако се ово не може сматрати репрезентативним узорком, аутори су се усмерили на опис искустава за која су претпоставили да су слична и код оних који на упитник нису одговорили, увидом у активности библиотека у објављеним радовима, на веб-страницама и на друштвеним мрежама.

Библиотекари матичних служби су дали веома разноврсне одговоре и то не на сва постављена питања те је урађена њихова анализа без квантитативних показатеља. Да би се подаци употпунили и сачинио што целовитији приказ, аутори су наводили и искуства библиотекара која су чули на овогодишњем Библионету одржаном у Лесковцу.

Упитник је садржао седам питања:

1. Опишите како је у вашој библиотеци организован рад у време проглашења ванредног стања због пандемије Covid-19 у току 2020. године. На који начин је организован рад са корисницима?

2. Колико је интензивирано присуство ваше библиотеке на друштвеним мрежама у току „затварања“ у пролеће 2020. године? Можете ли да наведете примере?

3. Када је и на који начин ваша библиотека поново отворила врата за кориснике након „затварања" у пролеће 2020. године?

4. Да ли је сада у вашој библиотеци у потпуности нормализован рад са корисницима или и даље постоје нека ограничења за њих? Опишите молим вас.

5. Да ли су радници ваше библиотеке током пандемије Covid-19 били друштвено ангажовани у помоћи локалној заједници и на који начин? Наведите примере.

6. Колико се ситуација са пандемијом одразила на програме за кориснике које ваша библиотека организује? Да ли су неки програми одложени, промењени...?

7. Можете ли да изнесете нека запажања и закључке о раду са корисницима у новим околностима?

Овако конципираним питањима учињен је покушај да се испитаницима омогући да пруже што потпуније одговоре, тј. да опширно опишу своја искуства у ванредним условима рада. У даљем тексту ће, у складу са редоследом питања, одговори бити представљени хронолошким редом. 
Јеремић П. и др. „Рад јавних библиотека у Србији у ванредним условима изазваним пандемијом Covid-19“, 35-46

\section{Затварање библиотека}

У циљу спречавања ширења пандемије корона вируса Covid-19, заједничком одлуком председника Републике, председника Народне скупштине и председника Владе Републике Србије (РС), ${ }^{1}$ 15. марта 2020. године уведено је ванредно стање у држави. ${ }^{2}$ С обзиром на спреченост обављања програмских активности установа културе и редукцију пословног процеса због забране окупљања, Министарство културе и информисања Републике Србије, 16. марта исте године, упутило је препоруку установама културе да се грађанима омогући максимална доступност дигиталних садржаја из области културе на интернет каналима и друштвеним мрежама. ${ }^{3}$

Позивајући се на поменуту одлуку Владе РС, готово све библиотеке у Србији прекинуле су непосредни рад са корисницима, што се може сматрати јединственим случајем у досадашњој пракси.

У складу са Уредбом о организовању рада послодаваца за време ванредног стања4 и препорукама Министарства за државну управу и локалну самоуправу, у јавним библиотекама је реорганизован ангажман запослених радника. Већи део је прешао на рад од куће. У почетку се ова препорука односила на оне који су сматрани посебно угроженима -хронични болесници, радници старији од 60 година, самохрани родитељи и родитељи деце до 12 година старости.

Један део запослених наставио је редовно да долази на посао. Осим потребе за дежурствима, настављен је стручни рад на уређењу фондова, каталогизацији, инвентарисању и ревизији, дигитализацији, као и свим осталим пословима који се одвијају независно од рада са корисницима (Зрењанин, Краљево, Шабац, Врање, Лесковац, Ниш, Нови Сад, Суботица, Панчево, Вршац, Бор, Ваљево, Библиотека града Београда).

Овакве измене радног режима морале су бити правно регулисане на нивоу сваке библиотеке. У том смислу, усвојени су документи као што су: Акт о процени ризика, Правилник о организацији рада током трајања ванредног стања, План примене мера заштите запослених и друга слична акта која су, укупно гледано, имала за циљ да се обезбеди заштита запослених и корисника приликом трајања пандемије, као и да се дефинише другачија организација рада (Зрењанин, Краљево, Суботица, Врање, Вршац, Лесковац). За разлику од осталих, Народна библиотека Крушевац је све време услуживала кориснике. У библиотеци у Бору, свим члановима је продужено чланство за 2 месеца, колико је била затворена физички за кориснике.

\section{Нов начин рада са корисницима}

На основу одговора испитаника, очигледно је да су се библиотеке веома брзо прилагодиле новом начину рада са корисницима користећи дигиталне технологије. Садржаје својих фондова нудиле су на својим веб-страницама, друштвеним мрежама, а програме и на YouTube каналима. Контакте са корисницима, тамо где то није било могуће у непосредним сусретима, библиотекари су остваривали телефоном, имејлом, путем Messenger-a, Viber-a, WhatsApp-а и др., док су библиотекари из Лесковца навели да су корисницима достављали

\footnotetext{
1 На основу „Закон о заштити становништва од заразних болести“, Службени ілласник Рейублике Србије бр. 15, члан 6, став 1 (2016) и других закона.

2 „Одлука о проглашењу болести COVID-19 изазване вирусом Sars-CoV-2 заразном болешћу“, Службени іласник Рейублике Србије број 35 (2020)

3 Министарство културе и информисања Републике Србије, Препорука установама културе да се грађанима Србије омогући доступност дигиталног садржаја“, објављено 16. 3. 2020, преузето 24. 6. 2021, https://www.kultura.gov.rs/vest/1637/preporukaustanovama-kulture-da-se-gradjanima-srbije-omoguci-dostupnost-digitalnih-sadrzaja.php.

4 „Уредба о организовању рада послодаваца за време ванредног стања“, Службени іласник Рейублике Србије број 31 (2020), објављено 16. 3 2020, преузето 24 6. 2021, https://www.pravno-informacioni-sistem.rs/SIGlasnikPortal/eli/rep/sgrs/vlada/ uredba/2020/31/2/reg.
} 
жељене публикације на кућну адресу. Неке библиотеке су комуникацију са корисницима обављале путем конференцијских апликација. Амерички кутак библиотеке у Врању, на пример, организовао је часове енглеског језика и обуку из медијске писмености путемZoom-a и Hangouts-a.

На веб-страницама библиотека објављиване су, на првом месту битне информације о раду библиотеке за време пандемије, електронски каталози фондова, садржаји о славним личностима и важни датуми, дигиталне библиотеке у којима се налазе електронска издања публикација, виртуелне изложбе, дигитализоване збирке периодичних публикација, презентације збирки, нарочито завичајних фондова и фондова старе и ретке књиге, препоруке књига за читање, звучне књиге итд. (Ниш, Суботица, Крушевац, Бор, Краљево, Зрењанин, Лесковац, Пожаревац, Шабац). ${ }^{5}$ Завичајно одељење библиотеке у Крушевцу, на пример, покренуло је посебну веб-страницу на којој су израђиване предметне одреднице о познатим Крушевљанима, местима и установама. ${ }^{6}$ На веб-страници библиотеке у Бору објављивани су постови о дисеминацији општих информација из културе, уметности и образовања, о локалној култури и животу и обичајима, анализиране историјске фактографије везане за Француско друштво борских радника (ФДБР), радничку културу и индустријско наслеђе у циљу писања публикације о фотодокументацији ФДБР. Ово је, уједно, једина библиотека која је навела да је одржавала блог Клуб књиіољубац, ${ }^{7}$

Многе библиотеке су процениле да корисници не прате њихове званичне веб-странице, па су своје активности првенствено усмериле на друштвене мреже и YouTube канале (Врање).

Активност библиотека била је највидљивија на Facebook-у (ФБ), Instagram-у и YouTube-y. У периоду забране кретања, корисници су овде могли да пронађу најразличитије садржаје.

Из Библиотеке града Београда, емитовано је девет великих програмских циклуса („Читам не скитам" - на ФБ страницу корисници су слали омиљене цитате из књига; фото-конкурс "Читај, не скитај, са књигом се сликај“ - YouTube канал и ФБ страна, „Прочитај ми моју жељу“ - читање поезије, „Причам, не скитам“ - серијал разговора са познатима, „Драгоцености библиотеке града Београда“ - виртуелна шетња кроз посебне фондове и одељења, "Фото-конкурс ретротека" - изложба најбољих фотографија, "Споменар БГБ“ - виртуелни споменар познатих, „Приче са путовања“ , „Библиотеке су свет“ уз учешће 13 амбасада, „Поезију ће сви волети“" итд.). ${ }^{8}$

Библиотека у Суботици је на ФБ-у и YouTube-y, сем помињаних садржаја, постављала снимке бајки и лектира које су, по избору библиотекара, читали глумци суботичког позоришта. ${ }^{9}$

На друштвеним мрежама Градске библиотеке у Новом Саду објављивани су цитати познатих на тему храбрости и разноврсни програми („Књиге које немају рок трајања“ - подсећање на класична дела светске књижевности; „Корисници читају“ - читаоци су слали снимке читања романтичне поезије; „Књига као облик уметничког изражавања“; "Шапутање на увце“ - библиотекари и познате личности читали су бајке и песме за децу; „Од детета до поете“

\footnotetext{
${ }^{5}$ Народна библиотека „Стеван Сремац“, Ниш, преузето 1. 7. 2021, http://www.nbss.rs/; Градска библиотека Суботица, преузето 1. 7. 2021, https://www.subiblioteka.rs/; Народна библиотека Крушевац, преузето 1. 7. 2021, https://nbks.org.rs/; Народна библиотека Бор, преузето 2. 7. 2021, https://www.biblioteka-bor.org.rs/; Народна библиотека "Стефан Првовенчани“, Краљево, преузето 2. 7. 2021, https://kv-biblio.org.rs/; Градска народна библиотека „Жарко Зрењанин“, Зрењанин, преузето 3. 7. 2021, https://www.zrbiblio.rs/; Народна библиотека „Радоје Домановић“, Лесковац, преузето 4. 7. 2021, https://www.nbleskovac.rs/; Народна библиотека „Илија М. Петровић“, Пожаревац, преузето 4. 7. 2021, http://www.nbpo.rs/; Библиотека шабачка, преузето 4. 7. 2021, https://bibliotekasabac.org.rs/.

${ }^{6}$ Народна библиотека Крушевац, Завичајно одељење, Крушевљни - е-база о Крушевиу и Крушевљанима“, преузето 10. 7. 2021, https://krusevljani.com/.

7 Народна библиотека Бор, Клуб књиіољубаца (блог), преузето 2. 7. 2021, http://knjigoljubac.blogspot.com/.

8 Biblioteka grada Beograda, Facebook, preuzeto 3. 7. 2021, https://www.facebook.com/bibliotekagradabeograda; Biblioteka grada Beograda, Youtube, preuzeto 3. 7. 2021, https://www.youtube.com/channel/UCx21nKdrIPAxUrj8-NT3Hfg.

${ }_{9}$ Gradska biblioteka Subotica (zvanična prezentacija), Facebook, preuzeto 3. 7. 2021, https://www.facebook.com/subotica.biblioteka; Gradska biblioteka Subotica, YouTube, preuzeto 3. 7. 2021, https://www.youtube.com/channel/UC6Z1X5MZj1sshyr6G999j0Q
} 
Јеремић П. и др. „Рад јавних библиотека у Србији у ванредним условима изазваним пандемијом Covid-19“, 35-46

- поетско-рецитаторски конкурс у онлајн форми; интервјуи са дечјим писцима, „Узречице и низречице“ - језичке недоумице и занимљивости; „Писци код вас“ - писци читају своја дела, „Речи као знамења“ - представљање нових књига). ${ }^{10}$

Библиотекари из Врања своје активности су усмерили на ФБ страницу, на којој су објављивали обавештења о библиотечким онлајн ресурсима, дигиталним садржајима, препоруке за читање, обележавали су значајне датуме за библиотекарство и књижевност. ${ }^{11}$

Зрењанинска библиотека је, такође, своје садржаје објављивала на друштвеним мрежама и YouTube каналу. Покренута је „Причаоница" - 192 аудио-приче које су читали одрасли, деца, библиотекари, а преслушане су више од 15.000 пута. У овај програм укључена је и Међуопштинска организација слепих и слабовидих. Објављивала је свакодневне препоруке Позајмног одељења у виду краћих ауторских рецензија. Корисници су показали велико интересовање за виртуелно вођење кроз изложбу „Старе књиге и рукописи ГНБ ,Жарко Зрењанин ${ }^{\prime \prime} .{ }^{2}$

Путем друштвених мрежа (ФБ и Instagram) Библиотека у Краљеву је објављивала информације о раду и промовисала нове облике програмских и радионичарских делатности. Презентовала је своје дигиталне колекције, фонд старе и ретке књиге, завичајни фонд, организовала културно-анимационе програме дечје библиотеке, а нарочито су били посећени књижевне вечери и концерти. Свакодневно је вођен онлајн читалачки дневник за одрасле и децу. Програм је настављен и након поновног отварања библиотеке. Покренута је онлајн говорна радионица за децу - сет говорних вежби (брзалица) и онлајн квиз о познавању књижевности за одрасле у част Светског дана књиге. ${ }^{13}$

Библиотекари из Лесковца су, од проглашења пандемије, све време корисницима и пратиоцима на друштвеним мрежама пружали разне информације. Објавили су 11 електронских каталога књига са предлозима за читање у ванредним околностима са Позајмног и Дечјег одељења. Израђен је и каталог књига на основу којег се могла поручити грађа. Библиотека је организовала бројне активности за децу и младе. Читање бајки и басни „Библиотекари читају за најмлађе" емитовано је сваког дана на друштвеним мрежама и YouTube каналу Библиотеке. У акцији под називом „Лаку ноћ, децо!“ објављивани су садржаји за најмлађе на српском и енглеском језику, а у њој су учествовала и сама деца која су читала песме или приче и слала своје видео-записе. Израђена је „Библиобојка“- електронска бојанка за најмлађе са цртежима књига и библиотеке. Такође су објављиване активности: „Читалац библиотекар“, „Библиотекари препоручују“, „На данашњи дан“, „Читање је лековито!“, „Знаменитости Лесковца“, „Цркве и манастири Лесковца“ и "Лесковачки аутори“. ${ }^{14}$

На ФБ страници библиотеке у Пожаревцу организована су онлајн књижевна представљања, предавања, занимљивости из света културе, радионице, наградни конкурси и прилози за децу - читање бајки и прича. ${ }^{15}$

\footnotetext{
${ }_{10}$ Gradska biblioteka u Novom Sadu, Facebook, preuzeto 4. 7. 2021, https://www.facebook.com/GradskaBibliotekaNoviSad; Градска библиотека у Новом Саду, YouTube, preuzeto 4. 7. 2021, https://www.youtube.com/c/\%D0\%93\%D1\%80\%D0\%B0 \%D0\%B4\%D1\%81\%D0\%BA\%D0\%B0\%D0\%B1 \%D0\%B8\%D0\%B1 \%D0\%BB\%D0\%B8\%D0\%BE\%D1\%82\%D0\%B5\%D0\%BA\%D0\%B0\%D1\%83\%D0\%9D\%D0\%BE\%D0\%B2\%D0\%BE\%D0\%BC\%D0\%A1\%D0\%B0\%D0\%B4\%D1\%83.

11 Javna biblioteka "Bora Stanković", Vranje, Facebook, preuzeto 4. 7. 2021, https://www.facebook.com/bibvr.

12 Gradska narodna biblioteka „Žarko Zrenjanin“, Zrenjanin, Facebook, preuzeto 4. 7. 2021, https://www.facebook.com/zrenjaninskabiblioteka; Gradska narodna biblioteka „Žarko Zrenjanin“, Zrenjanin, YouTube, preuzeto 4. 7. 2021, https://www.youtube. com/channel/UC8FBAcdt1LIrCHncekMR6lw.

13 Народна библиотека „Стефан Првовенчани“, Краљево, Facebook, preuzeto 4. 7. 2021, https://www.facebook.com/BibliotekaKraljevo. Аутори су информације допуњавали и подацима из текста Јелена Андрић и Данка Спасојевић, „Организација и изазови у раду Народне библиотеке ,Стефан Првовенчани' Краљево у доба пандемије“, Библиоешекар год. LXII Cв. 2 (2020): 85-97.

14 Народна библиотека „Радоје Домановић“, Лесковац, Facebook, preuzeto 4. 7. 2021, https://www.facebook.com/leskovac.biblioteka; Narodna biblioteka "Radoje Domanović", Leskovac, YouTube, preuzeto 4. 7. 2021, https://www.youtube.com/channel/ UCDOG3Uht8ZSM4jCz-ENLRQQ.

15 Народна библиотека „Илија М. Петровић“, Пожаревац Group, Facebook, preuzeto 4. 7. 2021, https://www.facebook.com/ groups/565891400932165.
} 
Као што се може приметити, један број испитаника је детаљније одговорио на питања о свом раду у време затварања, док су други били прилично штури. Неке библиотеке нису имале видљиве активности на својим веб-страницама и на друштвеним мрежама у посматраном периоду. Иако упитник није попунила већина библиотекара којима је послат, њихове библиотеке су биле веома активне, било у непосредном раду са корисницима, било у виртуелном окружењу. Неки испитаници су такође навели да су се одређени програми наставили и када је дошло до поновног отварања библиотека.

\section{Поновно отварање библиотека}

На основу препоруке Министарства културе и информисања свим библиотекама, архивима, музејима и галеријама да од среде 22. априла 2020. године наставе рад, ${ }^{16}$ почињу припреме за поновно отварање библиотека за кориснике. Све установе су биле дужне да обезбеде примену превентивних мера због здравља и безбедности запослених, а односиле су се на држање дистанце, дезинфекцију и употребу заштитних средстава, као и мера које се односе на максималан број лица која могу да бораве у затвореном простору. У овом акту се нису могла пронаћи детаљнија упутства како спроводити прописане мере, па су библиотекари били прилично несигурни како да поступе у новој ситуацији. Нажалост, нико се није позабавио психолошком подршком запосленима, али они свакако нису изузетак у прилично стихијском приступу заштити здравља и безбедности грађана.

Увидевши потребу за детаљнијим упутствима, Одељење за заштиту, конзервацију и рестаурацију Народне библиотеке Србије је 25. 4. 2020. издало Обавештење о руковању ірађом у условима йандемије вируса САРС-КОВ-2,17 које је, путем мреже, прослеђено свим библиотекама и било од велике користи за управљање библиотечком грађом у времену када се још није знало колико је могуће да се вирус преноси путем штампаних публикација. Институт за јавно здравље „Милан Јовановић Батут“ је донео Препоруке за рад библиотека, музеја и галерија, ${ }^{18}$ а Градски завод за

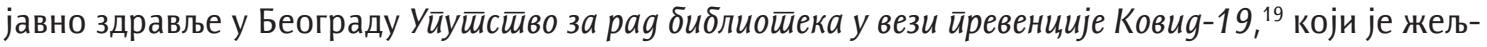
но дочекан и дељен у мрежи библиотечких установа. Библиотекарско друштво Србије (БДС) је, у захтевном и специфичном тренутку за сналажење у новим околностима, одиграло улогу информационог сервиса за библиотекаре. Председник Друштва, Богдан Трифуновић, 23. 4. 2020. упутио је, путем библиотечке виртуелне мреже, Преgлої ирейорука и мера раgа библиошека

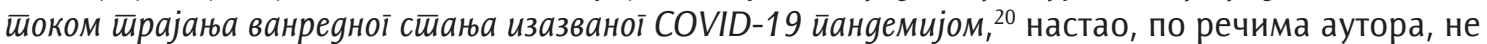
као обавезујуће упутство, него средство помоћи библиотекама које су се нашле у транзицији из ванредног начина рада у нормално стање. На основу ових докумената, испитаник из Зрењанина наводи да је библиотека донела план примене мера заштите запослених. ${ }^{21}$ Вероватно су и остале установе доносиле оваква акта, али испитаници их у својим одговорима нису навели.

\footnotetext{
${ }^{16}$ Министарство културе и информисања, „Препорука библиотекама, архивима, музејима и галеријама да од среде 22. априла 2020. године наставе рад", објављено 21. 4. 2020, преузето 7. 7. 2021, https://kultura.gov.rs/vest/1691/preporuka-bibliotekamaarhivima-muzejima-i-galerijama-u-srbiji-da-od-srede-22-aprila-2020-godine-nastave-rad.php.

17 Народна библиотека Србије, Одељење за заштиту, конзервацију и рестаурацију, Обавешшење о руковању ірађом у условима йанgемије вируса САРС-КОВ-2, имејл, 25. 4. 2020, интерна комуникација.

18 Институт за јавно здравље "Милан Јовановић Батут“, Прейоруке за раg библиошека, музеја и їалерија, преузето 10. 7. 2021, httр:// www.batut.org.rs/download/aktuelno/Biblioteke\%20muzeji\%20galerije.pdf.

19 Градски завод за јавно здравље, Београд, Уйуйсйво за раg библиоиеека у вези йревениије Ковиg-19, преузето 10. 7. 2021, https:// www.zdravlje.org.rs/filesnew/docs/Preporuke-kovid/Preporuke-za-rad-biblioteka.pdf.

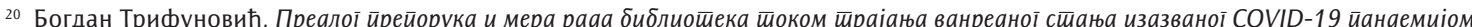
имејл 23. 4. 2020, интерна комуникација. Аутор, у пропратном тексту, наводи да су ове препоруке настале на основу „информација са доступних веб-сајтова америчких колега и њихових искустава".

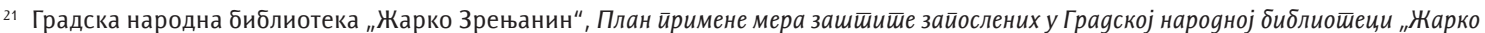
Зрењанин" Зрењанин за време йрајања ванреgної сйања, преузето 7. 5. 2020, http://www.zrbiblio.rs/images/Dokumenti/plan-primene-zastite-pandemija.pdf
} 
Јеремић П. и др. „Рад јавних библиотека у Србији у ванредним условима изазваним пандемијом Covid-19“, 35-46

Наведене препоруке и упутства су послужили као неопходне смернице у организацији корисничких сервиса, иако су у библиотекама морале да се доносе одлуке у складу са условима рада и разликовале су се од установе до установе. Из послатих одговора на упитник, могу се издвојити неколико начина на које су библиотеке организовале своје пословање.

Највећи број библиотекара наводи да су се библиотеке на почетку отвориле за кориснике у једној смени (Суботица, Панчево, Крушевац, Шабац, Бор, Зрењанин), остали нису прецизирали радно време те се претпоставља да су радиле у обе смене. Сви испитаници су одговорили да су се библиотеке постепено, али за врло кратко време, вратиле уобичајеном радном времену, т.. целог дана преко недеље и суботом пре подне. Једино су колеге из Лесковца организовале рад са пензионерима од 5-7 ујутру, кад су могли да изађу у куповину. Испитаник из Ниша тврди да је ова библиотека прва отворила врата корисницима без икаквих ограничења, што није могуће потврдити.

Што се начина рада са корисницима тиче, већина анкетираних наводи да су издавање публикација организовали преко шалтера (Суботица, Шабац) и инфо-пултова (Зрењанин, Нови Сад, Врање, Панчево, Бор, Лесковац). Књиге би се претходно наручивале телефоном, имејлом, преко Viber-а или Messenger-а или би корисници долазили са списком од десет књига, од којих су могли да преузму три (Ваљево). Све библиотеке су упућивале своје кориснике на електронске каталоге на својим веб-страницама. Колегиница из Краљева је једина навела да је овакав начин поручивања књига изазвао отпор код корисника, али је чињеница да су се све библиотеке суочиле са овим проблемом. Када је овај ограничени начин рада са корисницима у питању, аутори овога текста примећују да је поново дошао до изражаја дугогодишњи проблем недостатка простора и неадекватних зграда библиотека, тј. проценили су да простори у којима се налазе одељења за позајмљивање књига нису адекватни за безбедан долазак корисника. Неколико испитаника је навело да су корисници могли да уђу у просторије позајмних одељења, али не и у фонд (Ваљево, Бор) или да је приступ фондовима био дозвољен, са ограниченим бројем корисника на одељењима (Суботица, Пожаревац). Библиотекари из Вршца и Крушевца нису одговорили да ли је било ограничења броја корисника на позајмним одељењима. Јединствени одговор свих анкетираних је био да се у установама инсистира на ношењу заштитних маски и дезинфекцији простора.

У периоду непосредно после отварања библиотека, испитаници наводе да читаонице нису биле отворене (Суботица, Зрењанин) или да је у њима био омогућен боравак ограниченог броја корисника, у зависности од величине просторија у којима се налазе и уз поштовање превентивних мера заштите (Крушевац, Нови Сад, Врање, Панчево, Вршац, Пожаревац).

Сви анкетирани библиотекари истакли су да је, према наведеним упутствима, библиотечка грађа одлагана у просторије које су служиле као карантин, у периоду од 48 сати до пет дана најчешће 72 сата, потом дезинфикована и враћана у фондове.

Период поновног отварања библиотека карактерише опрезан приступ раду са корисницима. Упутства која су упућена установама била су у том процесу од велике помоћи. Такође, искуства националних библиотека, у којима се рад са корисницима искључиво обавља у читаоницама, а приступ фондовима није слободан, помогла су да се установе правила у комуникацији са корисницима на овај начин. Издавање публикација и боравак у читаоницама организовани су у складу са расположивим простором, уз инсистирање на дезинфекцији и ношењу заштитних маски. У свим библиотекама су постављене дезо-баријере, а у већини и заштитно стакло или плексиглас на пултовима.

Од краја априла 2020. године није било затварања или ограничења рада било које делатности у земљи. Епидемиолошка ситуација је од тада била боља или лошија, али строге мере које су примењене на почетку нису се поновиле. У међувремену је започета и вакцинација становништва која се спроводи са слабим ефектима. Ванредна ситуација и претња озбиљним последицама заражавања предуго траје, па је неминовно дошло до опуштања, неношења заштитних маски, непоштовања противепидемиолошких мера. Пандемији се не види још увек крај, али 
се до сада, из претходно написаног, може приметити да су библиотекари, уз извесне изузетке, схватили озбиљност тренутка и показали велику одговорност у комуникацији са корисницима ради заштите живота и здравља.

\section{Друштвени ангажман библиотека и библиотекара за време пандемије}

Као сервиси заједнице, библиотеке су, у посматраном периоду, ангажоване на помоћи најугроженијим групама и на заштити здравља у локалној средини. Већина активности које су описане у одговорима испитаника организованаје на добровољној бази, али се мора приметити и намера локалних самоуправа да се што већи број радника у јавним установама додатно ангажује на различитим пословима у вези са сузбијањем последица пандемије на животе људи.

Велики број библиотека поседује 3D штампаче, па су библиотекари из Зрењанина и Лесковца штампали визире намењене медицинским радницима. Библиотекари у Шапцу су у просторијама установе шили памучне маске које су дељене бесплатно у граду и у селима.

Остале активности биле су намењене становништву. Зрењанински библиотекари су били ангажовани у градском кол-центру на пружању информација грађанима и координацији помоћи најугроженијм групама, а када је почело пријављивање за вакцинацију, позивали су становнике и обавештавали их о терминима. Млађи радници библиотеке у Бору такође су ангажовани у градском кол-центру за достаљање информација, намирница и лекова старијим суграђанима, као и библиотекари из Лесковца и Шапца, који су паковали хигијенске пакете намењене пензионерима. Шабачки библиотекари су радили и у градској служби за помоћ пензионерима и осталим угроженим категоријама грађана. Они су достављали помоћ у храни и осталим потрепштинама. Учествовали су и у акцији поделе заштитних маски и дезинфекцији простора.

Најзанимљивији одговор на питање о друштвеном ангажовању библиотека и библиотекара стигао је из Крушевца. Наиме, колеге су у градској хали спортова, која је била преуређена у Covid болницу, припремиле малу покретну библиотеку за болеснике. Из Градског штаба су их обавестили да код хоспитализованих нема интересовања за читањем.

\section{Утицај пандемије на културне програме у јавним библиотекама}

Промотивне активности библиотека су незаобилазни део њиховог пословања и комуникације са локалном заједницом. Проглашењем пандемије постало је јасно да промоције књига, изложбе, радионичарски рад са децом и одраслима, читалачки клубови и остале активности које су се организовале у затвореним просторима установа неће бити одржане. Као што је речено у одељку о деловању библиотека у виртуелном свету, ове установе су врло брзо модификовале своје програме и прилагодиле их новонасталим околностима и дигиталном окружењу. Активности на мрежама су настављене и након отварања јер су их корисници добро прихватили, а број посета на YouTube каналима и на друштвеним мрежама значајно је порастао. Међутим, популација махом старијих и социјално угрожених суграђана који су били редовни посетиоци различитих манифестација није вична новим технологијама, не поседује опрему ни друштвене мреже, па је остала ускраћена за културне садржаје које су нудиле библиотеке.

Већина програма и манифестација јавних библиотека која је требало да се одржи у марту, априлу и мају 2020. године је одложена или отказана, навели су сви испитаници у својим одговорима. Како се епидемиолошка ситуација смиривала, опрезно су заказиване поједине активности, уз строго поштовање заштитних мера (Зрењанин, Нови Сад, Суботица, Вршац, Пожаревац). Неки испитаници су се изјаснили да су отказали, одложили програме или их свели на најмању меру, очекујући тренутак када ће проценити да је безбедније да се одрже (Бор, Шабац, Крушевац, Вршац, Ваљево, Лесковац). Радионице са мањим бројем учесника, уз мере опреза, одржаване су у затвореном простору (Зрењанин, Крушевац). 
Јеремић П. и др. „Рад јавних библиотека у Србији у ванредним условима изазваним пандемијом Covid-19“, 35-46

После отварања библиотека, пролеће и лето су искориштени да се манифестације, радионице и друге активности организују на отвореном простору (Крушевац, Зрењанин). Иста пракса се наставила и 2021. године, када су лепо време и мирнија епидемиолошка ситуација дозвољавали да се на отвореном окупи већи број заинтересованих људи.

Међутим, традиционалне активности и манифестације су се веома брзо прилагодиле условима онлајн окружења, па су, када је то било могуће, одржаване у оба облика-у непосредном контакту са корисницима и у виртуелном окружењу (Суботица, Краљево) или искључиво на дигиталним платформама (Нови Сад, Краљево). У Нишу су, према ономе што су представили, програми библиотеке текли уобичајено, али и овде су програми презентовани на друштвеним мрежама наставили да се развијају и после отварања. У Врању је два пута одлагани Библионет 2020. ипак одржан од 1. до 3. октобра.

\section{Закључци и запажања учесника у анкети}

Последње питање из упитника о запажањима и закључцима испитаника формулисано је прилично уопштено те су добијени прилично разноврсни одговори. Из њих се ипак може извести низ важних закључака.

Један део испитаника исказао је своја негативна запажања на основу увида у тренутно пословање својих установа. Она се односе на смањење броја корисника и опадање броја пружених услуга (Вршац, Нови Сад) или на то да се онлајн ресурси нису користили у очекиваној мери због традиционалног начина коришћења библиотечке грађе и извора (Бор). Наведене су и замерке корисника које су се односиле на немогућност коришћења читаоница и слободног кретања кроз фондове (Ваљево, Зрењанин).

Међутим, већина одговора изражавала је велики оптимизам јер су библиотекари, принуђени да се снађу у новим околностима, то урадили успешно и исказали велику креативност. Библиотеке су увећале своје присуство у виртуелном окружењу и показале се флексибилним и технички припремљеним за пружање услуга на нови начин. Тиме су добиле и нове кориснике, а забележена је и појава да се они навикнути на традиционалну комуникацију прилагођавају новим околностима. Најзначајнија је чињеница да су корисници услужени, што је основни задатак библиотека. Пандемија је убрзала тренд улагања у дигиталне ресурсе који би требало наставити јер је потребно ојачати дигиталне садржаје посебно у домену образовања и пружања услуга на даљину.

Испитаници су истакли да је пандемија допринела преиспитивању досадашњих стратегија и начина рада, тако да је неопходно позабавити се компетенцијама и образовањем запослених. Такође, очекује се да ће се убрзати промене које су већ најављиване, али и одлагане. Државна управа би требало да размисли о увођењу флексибилнијих аранжмана за запослене у култури - рад на даљину, клизно или скраћено радно време итд. (Ниш, Библиотека града Београда, Нови Сад, Врање, Крушевац, Краљево, Пожаревац, Зрењанин).

\section{Закључак}

Аутори су у овом раду желели да направе пресек рада јавних библиотека у Републици Србији у ванредним околностима изазваним пандемијом Covid-19. Са том идејом је послат Упитник чија питања су конципирана тако да омогуће што разноврснији и опширнији приказ активности рада ових установа. С обзиром на чињеницу да га је попунило мање од половине библиотекара матичних служби, допуњен је подацима из излагања на Библионету 2021 у Лесковцу, као и прегледом веб-страница и друштвених мрежа матичних библиотека у држави. Одговори испитаника нису били уједначени, неки су били прилично опширни, док су други били штури, али су у овом тексту пренети прилично верно.

На основу питања из Упитника, делатност библиотека је приказана хронолошким редом, од проглашења ванредног стања и затварања у марту до поновног отварања у априлу и мају 2020. 
године. Наведени су најзначајнији документи - акта, упутства и препоруке, који су помогли библиотекама да створе што безбедније окружење за своје корисинике, али и за запослене и да заштите своје фондове. Такође, наведени су и сви они стручни послови - сређивање фондова, каталогизација, инвентарисање, ревизија, дигитализација,који нису видљиви широј јавности, а којима су се библиотекари свакодневно бавили. Један број анкетираних колега је навео да су ови послови били најзаступљенији у посматраном периоду, па се кроз приказ активности оне најмање примећују и помињу, али се не могу сматрати мање важним.

Истраживање је показало и да су запослени у библиотекама били веома активни у локалној заједници и обављали најразличитије послове који не спадају у њихов стручни рад, али су значајни у пружању помоћи у заштити здравља и живота људи у условима глобалне пандемије.

Од тада није било нових затварања и промена режима рада, тако да и библиотеке настављају да обављају своје функције директним контактима са корисницима у просторијама установа, али и у виртуелном окружењу. Праћењем веб-страница и друштвених мрежа јавних библиотека може се са сигурношћу тврдити да су оне и пре пандемије биле активне у дељењу информација и својих садржаја, па се чини да овај присилни прелазак на комуникацију у виртуелном свету није био баш толико нов. Међутим, оног тренутка када је постао и једини, у условима када су директни контакти са корисницима били редуковани, библиотекари су постали маштовитији, активнији и заинтересованији за представљање у виртуелном свету. Стога је део рада који описује делатности библиотека на веб-странама и друштвеним мрежама опширинији и приказује прилично иновативне програме.

Закључци које су сами испитаници издвојили могу се поделити на песимистичне и оптимистичне. Очигледно је да су библиотекари забринути због смањења броја директних корисника и посета установама, као и због незадовољства које су они показивали због тога што нису могли да бораве у читаоницама, нити да слободно бирају публикације из фондова. Чињеница је да су многи чланови библиотека, посебно они који се не сналазе у виртуелном окружењу и не користе друштвене мреже, остали ускраћени за одређене садржаје, али један од одговора библиотекара је био да су сви корисници који су им се обратили били услужени, што се, по мишљењу аутора, може применити на све библиотеке. Оптимистични закључци се односе на креативност библиотекара и на флексибилност институција да се прилагоде новом окружењу и новим условима рада. Резултат ових активности је привлачење нових циљних група и стварање другачијих навика. Праћење нових технологија се показало веома значајним у ванредним животним околностима којима се не види крај. Општи закључак се може формулисати тако да ће библиотеке наставити са својим активностима у директним контактима, али и у виртуелном свету и да ће својим садржајима и даље бити важан чинилац друштвеног живота заједнице.

\section{Литература и извори:}

1. Andrić, Jelena i Danka Spasojević. „Organizacija i izazovi u radu Narodne biblioteke 'Stefan Prvovenčani' Kraljevo u doba pandemije“. Bibliotekar god. LXII sv. 2 (2020): 85-97.

2. Biblioteka grada Beograda. Facebook. Preuzeto 3. 7. 2021. https://www.facebook.com/ bibliotekagradabeograda.

3. Biblioteka grada Beograda. YouTube. Preuzeto 3. 7. 2021. https://www.youtube.com/channel/ UCx21nKdrIPAxUrj8-NT3Hfg.

4. Biblioteka šabačka. Preuzeto 4. 7. 2021. https://bibliotekasabac.org.rs/.

5. Gradska biblioteka Subotica (zvanična prezentacija). Facebook. Preuzeto 3. 7. 2021. https://www.facebook.com/subotica.biblioteka.

6. Gradska biblioteka Subotica. Preuzeto 1. 7. 2021. https://www.subiblioteka.rs/.

7. Gradska biblioteka Subotica. YouTube. Preuzeto 3. 7. 2021. https://www.youtube.com/channel/ UC6Z1X5MZj1sshyr6G999j0Q. 
Јеремић П. и др. „Рад јавних библиотека у Србији у ванредним условима изазваним пандемијом Covid-19“, 35-46

8. Gradska biblioteka u Novom Sadu. Facebook. Preuzeto 4. 7. 2021. https://www.facebook.com/ GradskaBibliotekaNoviSad.

9. Gradska biblioteka u Novom Sadu. YouTube. Preuzeto 4. 7. 2021, https://www.youtube.com/c/\%D0 \%93\%D1\%80\%D0\%B0\%D0\%B4\%D1\%81\%D0\%BA\%D0\%B0\%D0\%B1\%D0\%B8\%D0\%B1\%D0\%BB\%D0\%B8\%D0\%BE\%D1\%82\%D0\%B5\%D0\%BA\%D0\%B0\%D1\%83\%D0\%9D\%D0\%BE\%D0\%B2\%D0\%BE\%D0\%BC\%D0\%A1\%D0\%B0\%D0\%B4\%D1\%83.

10. Gradska narodna biblioteka „Žarko Zrenjanin“, Zrenjanin. Preuzeto 3. 7. 2021. https://www.zrbiblio. $\mathrm{rs} /$.

11. Gradska narodna biblioteka „Žarko Zrenjanin“, Zrenjanin. Facebook. Preuzeto 4. 7. 2021. https://www. facebook.com/zrenjaninskabiblioteka.

12. Gradska narodna biblioteka „Žarko Zrenjanin“, Zrenjanin. Plan primene mera zaštite zaposlenih u Gradskoj narodnoj biblioteci "Žarko Zrenjanin“ Zrenjanin za vreme trajanja vanrednog stanja. Preuzeto 7. 5. 2020. http://www.zrbiblio.rs/images/Dokumenti/plan-primene-zastite-pandemija.pdf.

13. Gradska narodna biblioteka „Žarko Zrenjanin“, Zrenjanin. YouTube, Preuzeto 4. 7. 2021. https://www. youtube.com/channel/UC8FBAcdt1LIrCHncekMR6lw.

14. Gradski zavod za javno zdravlje, Beograd. Uputstvo za rad biblioteka u vezi prevencije Kovid-19. Preuzeto 10. 7. 2021. https://www.zdravlje.org.rs/filesnew/docs/Preporuke-kovid/Preporuke-za-rad-biblioteka. pdf.

15. Institut za javno zdravlje "Milan Jovanović Batut". Preporuke za rad biblioteka, muzeja i galerija. Preuzeto 10. 7. 2021. http://www.batut.org.rs/download/aktuelno/Biblioteke\%20muzeji\%20galerije.pdf.

16. Javna biblioteka "Bora Stanković", Vranje. Facebook. Preuzeto 4. 7. 2021. https://www.facebook.com/ bibvr.

17. Ministarstvo kulture i informisanja Republike Srbije. „Preporuka bibliotekama, arhivima, muzejima i galerijama da od srede 22. aprila 2020. godine nastave rad“. Objavljeno 21. 4. 2020, preuzeto 7. 7. 2021. https://kultura.gov.rs/vest/1691/preporuka-bibliotekama-arhivima-muzejima-i-galerijama-u-srbiji-da-od-srede-22-aprila-2020-godine-nastave-rad.php.

18. Ministarstvo kulture i informisanja Republike Srbije. „Preporuka ustanovama kulture da se građanima Srbije omogući dostupnost digitalnog sadržaja“. Objavljeno 16. 3. 2020, preuzeto 24. 6. 2021. https:// www.kultura.gov.rs/vest/1637/preporuka-ustanovama-kulture-da-se-gradjanima-srbije-omoguci-dostupnost-digitalnih-sadrzaja.php.

19. Narodna biblioteka Bor. Preuzeto 2. 7. 2021. https://www.biblioteka-bor.org.rs/.

20. Narodna biblioteka Bor. Klub knjigoljubaca (blog). Preuzeto 2. 7. 2021. http://knjigoljubac.blogspot.com/.

21. Narodna biblioteka „Ilija M. Petrović", Požarevac Group. Facebook. Preuzeto 4. 7. 2021. https://www. facebook.com/groups/565891400932165.

22. Narodna biblioteka "Ilija M. Petrović“, Požarevac. Preuzeto 4. 7. 2021. http://www.nbpo.rs/.

23. Narodna biblioteka Kruševac. Preuzeto 1. 7. 2021. https://nbks.org.rs/.

24. Narodna biblioteka Kruševac, Zavičajno odeljenje. Kruševljni-e-baza o Kruševcu i Kruševljanima. Preuzeto 10. 7. 2021, https://krusevljani.com/.

25. Narodna biblioteka „Radoje Domanović", Leskovac. Preuzeto 4. 7. 2021. https://www.nbleskovac.rs.

26. Narodna biblioteka "Stevan Sremac", Niš. Preuzeto 1. 7. 2021, http://www.nbss.rs/.

27. Narodna biblioteka "Stefan Prvovenčani", Kraljevo. Preuzeto 2. 7. 2021. https://kv-biblio.org.rs/.

28. Narodna biblioteka "Stefan Prvovenčani“. Kraljevo. Facebook. Preuzeto 4. 7. 2021. https://www.facebook.com/BibliotekaKraljevo.

29. „Odluka o proglašenju bolesti COVID-19 izazvane virusom Sars-CoV-2 zaraznom bolešću“. Službeni glasnik Republike Srbije broj 35 (2020).

30. „Uredba o organizovanju rada poslodavaca za vreme vanrednog stanja“. Službeni glasnik Republike Srbije broj 31 (2020). Objavljeno 16. 3 2020, preuzeto 24. 6. 2021. https://www.pravno-informacioni-sistem. rs/SIGlasnikPortal/eli/rep/sgrs/vlada/uredba/2020/31/2/reg.

31. "Zakon o zaštiti stanovništva od zaraznih bolesti“. Službeni glasnik Republike Srbije br. 15, član 6, stav 1 (2016). 
Јеремић П. и др. „Рад јавних библиотека у Србији у ванредним условима изазваним пандемијом Covid-19“, 35-46

\title{
Work of Public Libraries in Serbia in Situation Caused by the Covid-19 Pandemic
}

\begin{abstract}
Summary
The text deals with the work of public libraries in Serbia in conditions caused by the Covid-19 pandemic. It is based on the questionnaire sent to the librarians of parent departments, members of the Section for the Parent Libraries of the Serbian Library Association. Since less than half of the colleagues answered the questionnaire, the authors supplemented their knowledge with the data presented during Biblionet, the professional and scientific meeting held in Leskovac in 2021, which was dedicated to this topic. The respondents' answers were presented and interpreted, and attention was also given to the activities of public libraries on the official websites and social networks. This research provides an overview of the activities of libraries in the conditions of emergency and imminent danger to human health and lives. It shows the redirection of communication with users from the traditional provision of services in the institutions to a new, digital environment. It has been proven that these institutions have quickly and successfully adapted to the new circumstances and managed to animate a new user group by presenting their funds, collections, exhibitions, events, and various activities in the virtual world. The conclusions singled out by the respondents themselves can be divided into pessimistic and optimistic. It is obvious that librarians were concerned about the declining number of direct users and visits to the institutions, as well as about the users' dissatisfaction with the impossibility of staying in reading rooms and freely searching books in library funds. It is the fact that many of the users, especially those who do not cope well with a virtual environment and do not use social networks, have been deprived of certain contents, but one of the answers of the librarians who participated in the research, which, in the opinion of the authors, could be applied to all libraries, was that all the users who approached librarians were given service. Optimistic conclusions refer to the creativity of librarians and the flexibility of institutions to adapt to the new environment and new working conditions. The result of these activities is attracting new user groups and creating different habits. The general conclusion is that the libraries will continue working in direct contact with the users but will also work in the virtual world and that their activities will continue being an important part of the social life of local communities.
\end{abstract}

Keywords: public libraries, Republic of Serbia, Covid-19 pandemic, web pages, social networks, library funds, digital technologies, promotional activities, online services

Примљено: 26. октобра 2021

Исправке рукописа: 8. новембра 2021 Прихваћено за објављивање: 11. новембра 2021 